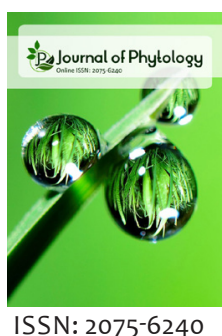

ISSN: $2075-6240$

\title{
Some nutritional properties of Taiwan Napier grass leaves (Pennisetum purpureum) harvested at different time
}

\author{
Masnindah Malahubban ${ }^{1 *}$, Nur Zahirah Abd Jalil'2, Fitri Ab Aziz Zakry,3, \\ Juriah Kamaludeen', Mohammad Nasir Hassan', Noorasmah Saupi ${ }^{2,3}$
}

\begin{abstract}
'Department of Animal Science and Fishery, Faculty of Agricultural Science and Forestry, Universiti Putra Malaysia Bintulu Sarawak Campus, 97008 Bintulu, Sarawak, Malaysia, ${ }^{2}$ Department of Crop Science, Faculty of Agricultural Science and Forestry, Universiti Putra Malaysia Bintulu Sarawak Campus, 97008 Bintulu, Sarawak, Malaysia,
\end{abstract} 3Institut Ekosains Borneo, Universiti Putra Malaysia Bintulu Sarawak Campus, 97008 Bintulu, Sarawak, Malaysia

Received: January 01, 2021 Revised: May 14, 2021 Accepted: May 17, 2021 Published: June 04, 2021

*Corresponding Author: Malahubban $M$

E-mail: masnindah@upm.edu.my KEYWORDS: Forage, Leaf, Napier, Nutrients, Pennisetum purpureum

\section{INTRODUCTION}

Napier grass (Pennisetum purpureum) is a fast-growing monocot grass belonging to the family Poaceae and morphologically stout, tall and deep-rooted perennial bunchgrass and mainly propagated through stem cutting. It is used primarily as a feed crop (fodder grass) for livestock. Napier grass is currently the most popular fodder grass in dairy and feedlot production systems due to high productivity and good nutritive value (Wadi et al., 2014). This grass is productive, easy to cultivate, droughttolerant and adaptable to various soil and climatic conditions, especially under different tropical soils (Halim et al., 2013). Livestock production requires a substantial amount of nutrients for growth and reproduction. Napier grass can provide nutrients sourced from naturally grown or farming. Determining the level of feed nutrients is vital to ensure that the nutrients' level meets growth and reproduction requirements. Additional feed input may be required to fulfil a dietary requirement. Besides that, evaluating the nutritional status at different growth or maturity stages is also essential. The growth or maturity stages may affect plant certain dietary content when growing on different soil types and environment (Lounglawan et al., 2013). Each soil type and location may alter Napier grass levels, thus influencing the animal feed quality. For example, Zailan et al. (2016) reported that dwarf Napier cultivar exhibited different nutritional potential at different harvesting ages. The crude protein was at maximum peaked when harvested during the sixth week. The dry matter was at a maximum when harvested during the eighth week. This phenomenon indicates that the time of harvesting has different consequences on nutritional composition. Therefore, this research aims to evaluate Napier cultivar Taiwan's chemical composition content at different harvesting time.

\section{MATERIALS AND METHODS}

This experiment conducted at the pasture field at Ladang Kongsi 1, Pasture Unit of University Agricultural Park located at the Universiti Putra Malaysia Bintulu Sarawak Campus, Sarawak, Malaysia, from October 2018 to January 2019. The average daily temperature at the field during planting and the growing season was $29-36^{\circ} \mathrm{C}$. Napier grass of Taiwan cultivar

Copyright: $\odot$ The authors. This article is open access and licensed under the terms of the Creative Commons Attribution License (http://creativecommons.org/licenses/by/4.o/) which permits unrestricted, use, distribution and reproduction in any medium, or format for any purpose, even commercially provided the work is properly cited. Attribution - You must give appropriate credit, provide a link to the license, and indicate if changes were made. 
used. About $20 \mathrm{~cm}$ length of fresh stem cuttings of Taiwan Napier grass was prepared for field planting and transplanted on the soil with $45^{\circ}$ angle with two nodes buried in the ground. The type of soil covers the area was under Bekenu soil series and characterised as subtle loamy, siliceous, isohyperthermic, red yellow to yellow. The structure is a weak medium to coarse subangular blocky and friable (Paramananthan, 2000). The cuttings arranged in the plot with planting distance between cuttings was $30 \mathrm{~cm}$ and between row at $60 \mathrm{~cm}$. Observations made, and care, maintenance and watering conducted as per standard practices. During growing days, subsampling of leaf and stem of Taiwan Napier grass was achieved by manual harvesting using sickle at $15,30,45,60,75$, and 90 days after planting. The random harvesting for samples performed at three different points. All plant samples cut into small pieces $(2-5 \mathrm{~cm})$ for oven-drying, which taken four to seven days to achieve constant weight before further analysis. Dried leaf and stem samples were then ground into a powder then sieved to pass through $2 \mathrm{~mm}$ mesh sieve.

Powdered samples in triplicates were then ready for proximate analysis. The parameters were the percentages of dry matter, moisture content, ash, crude fibre, ether extract, crude protein, and acid detergent fibre. Determination of dry matter, moisture content, and ash were following AOAC Method (AOAC, 1990). The crude fibre was determined, according to Van Soest et al. (1990) using the fibertec system. Crude fat determined by extracting a known weight of powdered plant sample with petroleum ether, using Soxtec system-tecator according to method 930.09, AOAC method (AOAC, 2000). The petroleum ether used for fat extraction then evaluated for weight percentage. Crude protein was determined using the total $\mathrm{N} \mathrm{Kjeldahl} \mathrm{method} \mathrm{and} \mathrm{then} \mathrm{transformed} \mathrm{using} \mathrm{the}$ conversion factor (6.25) to obtain crude protein (ConklinBrittain et al., 1999). Van Soest et al. (1990) method used to determined acid detergent fibre. This study analysed all data for the variance. Means comparison among sample's proximate analysis data of leaves and stem (dry matter, moisture content, ash, crude fibre, ether extract, crude protein, and acid detergent fibre) of different days $(15,30,45,60,75$, and 90 days after planting) were separated by least significance difference at $5 \%$ significance level. The data analysis conducted using SAS Statistical Software version 9.4.

\section{RESULTS AND DISCUSSION}

Proximate composition of Napier grass leaves over the different days were different significantly $(\mathrm{p}<0.05)$, except crude protein which recorded no different over a growing period up to 90 days (Table 1). Dry matter of Taiwan Napier grass leaves was increasingly higher from 75 days after planting up to harvesting day 90 . The dry matter was in the range of $12 \%$ to $18 \%$, where the dry weight went higher when older. However, at day 30 , the dry leaf matter was significantly lowered (12.02 $\pm 0.17 \%)$. This phenomenon may be associated with the fluctuation on plant water uptake and intense metabolic and physiological activities at the early growing stage (Jing and Malladi, 2020). Thus, lower dry matter indicates that higher plant water content consistently showed in Taiwan Napier grass leaves' moisture content recorded significantly lower moisture content when the plant gets older from day 30 to 90 (88\% to 82\% moisture content). The present study indicates that the crude fibre in Taiwan Napier grass leaves was significantly lower at day 15 . The crude fibre increased at 30 days after planting not changed during day 30 until day 90 . Crude fat was significantly different in every harvesting date. The crude fat of Napier leaves was fluctuating over 90 days of growth after planting. Taiwan Napier grass leaves' crude fat was at the lowest level at day $90(1.00 \%)$ but highest at early development (day 15) at 3.28\%. This outcome indicates that the crude fat of Taiwan Napier grass was lower when the Taiwan Napier grass went older. In contrast, Imoro (2020) stated that the crude fat in indigenous savanna forage shrub species in Ghana was more excellent at the matured plant stage. Different species and climatic condition may be changing the role and structure of fat in the plant is a plausible explanation.

The present study found that Taiwan Napier grass leaves' crude protein had not changed during 15 to 90 days of growth. This study is similar to Napier variety "Red" as reported by Zailan et al. (2016), who indicates that the "Red" variety was unchanged on week-4 to week-8 of harvesting dates. However, in a similar study, a different phenomenon was observed on the dwarf variety, which indicates decreased crude protein with increasing maturity. The acid detergent fibre (ADF) content had slight fluctuation over the growing period. The ADF content was highest at 30 days after planting (33\%) at lowest at 75 days after planting (23\%). This finding indicates that the ADF content was high during early growth and was low when Napier grass went older. In contrast, Rambau et al. (2016) demonstrated that Napier grass's ADF content was lower from early to the intermediate growing stage and higher at the older growth stage. The present study suggested that the difference in ADF content of Taiwan Napier grass from this study with other studies much related to the variety used in the study.

Table 1: Proximate compositions of Taiwan Napier grass at different harvesting time

\begin{tabular}{|c|c|c|c|c|c|c|}
\hline \multirow[t]{2}{*}{ Composition (\%) } & \multicolumn{6}{|c|}{ Days after planting } \\
\hline & 15 & 30 & 45 & 60 & 75 & 90 \\
\hline Dry matter & $13.82^{b} \pm 0.30$ & $12.02^{\mathrm{c}} \pm 0.17$ & $14.40^{b} \pm 0.40$ & $14.10^{b} \pm 0.44$ & $17.58^{\mathrm{a}} \pm 0.38$ & $18.00^{a} \pm 0.25$ \\
\hline Moisture & $86.18^{b} \pm 0.30$ & $87.98^{\mathrm{a}} \pm 0.17$ & $85.60^{b} \pm 0.40$ & $85.90^{b} \pm 0.44$ & $82.42^{\mathrm{c}} \pm 0.38$ & $82.00^{c} \pm 0.25$ \\
\hline Ash & $6.13^{\mathrm{ab}} \pm 0.06$ & $6.42^{a} \pm 0.46$ & $6.82^{\mathrm{a}} \pm 0.21$ & $6.32^{a} \pm 0.20$ & $5.07^{b} \pm 1.55$ & $5.70^{\mathrm{ab}} \pm 0.13$ \\
\hline Crude fibre & $28.17^{b} \pm 1.04$ & $34.50^{\mathrm{a}} \pm 0.50$ & $34.83^{a} \pm 0.29$ & $36.50^{a} \pm 1.80$ & $34.17^{a} \pm 3.01$ & $35.00^{a} \pm 1.32$ \\
\hline Crude fat & $3.28^{\mathrm{a}} \pm 0.21$ & $2.72^{b} \pm 0.20$ & $1.79^{c} \pm 0.13$ & $2.27^{b c} \pm 0.20$ & $2.01^{c} \pm 0.12$ & $1.00^{\mathrm{d}} \pm 0.59$ \\
\hline Crude protein & $14.59^{a} \pm 2.53$ & $18.24^{a} \pm 4.56$ & $20.43^{a} \pm 9.11$ & $21.89^{a} \pm 4.38$ & $17.51^{a} \pm 4.38$ & $15.32^{a} \pm 2.19$ \\
\hline Acid detergent fibre & $27.55^{b} \pm 2.26$ & $32.64^{a} \pm 5.05$ & $29.32^{\mathrm{ab}} \pm 0.34$ & $26.96^{b} \pm 0.13$ & $22.54^{c} \pm 0.55$ & $25.92^{b c} \pm 0.50$ \\
\hline
\end{tabular}

Different letters within the same row indicate a significant difference ( $L S D, p<0.05$ ) among different days. Value is the mean \pm standard deviation. 
The present study recommends that the best harvesting time was between 45 to 60 days after planting. The harvesting time was considerably similar in many research studies and practical recommendation at 42 days after planting (Turano et al., 2016; Haryani et al., 2018; Rahman et al., 2019). Even though, at 75 days of growth gave better dry matter yield (17.58 $0.38 \%$ ), the total minerals content (ash content) of Taiwan Napier grass significantly reduced. The minerals are essential for growth, physiology, and livestock metabolism and may create nutrients imbalance or under-nutrition if less (Masters et al., 2020). Other important nutritional components, such as crude protein (necessary for growth and muscular development), crude fibre, and crude fat (both are an essential energy source), were standard. They may not affect the overall dietary requirement and balance for livestock growth.

\section{CONCLUSION}

In conclusion, the present study found that most of the nutritional compositions in Taiwan Napier grass grown up to 90 days are variable. However, crude protein was no difference at the same time of growth. The present study suggests that the best time harvesting of Taiwan Napier grass for livestock feeding was between 45 and 60 days after planting. This finding is useful as baseline data that provides information on Napier's nutritional composition grown at a particular cropping site. It helps plan and strategy for new planting activity, especially when determining the best time for harvesting.

\section{ACKNOWLEDGEMENTS}

This study was financially supported by Fundamental Research Grant Scheme (FRGS) of the Ministry of Higher Education Malaysia (MOHE) (MOHE Reference Code: FRGS/1/2017/ WAB01/UPM/02/2). Authors thank Taman Pertanian Universiti of the Universiti Putra Malaysia Bintulu Campus Sarawak for providing area and facilities to conduct this work.

\section{REFERENCES}

AOAC. (1990). Official methods of analysis of the Association of Official Analytical Chemists. (15th Eds.), Washington D.C.: Association of Official Analytical Chemists (AOAC).

AOAC. (2000). Official Methods of Analysis of the Association of Official Analytical Chemists. (17 $7^{\text {th }}$ Eds.), Arlington: Association of Official
Analytical Chemists (AOAC).

Conklin-Brittain, N. L., Dierenfeld, E. S., Wrangham, R. W., Norconk, M., and Silver, S. C. (1999). Chemical protein analysis: a comparison of Kjeldahl crude protein and total ninhydrin protein from wild, tropical vegetation. Journal of Chemical Ecology, 25(12), 2601-2622. https:// doi.org/10.1023/A: 1020835120701

Halim, R. A., Shampazuraini, S., and Idris, A. B. (2013). Yield and nutritive quality of nine Napier grass varieties in Malaysia. Malaysian Journal of Animal Production, 16, 37-44.

Haryani, H., Norlindawati, A. P., Norfadzrin, F., Aswanimiyuni, A., and Azman, A. (2018). Yield and nutritive values of six Napier (Pennisetum purpureum) cultivars at different cutting age. Malaysian Journal of Veterinary Research, 9(2), 6-12.

Imoro, Z. A. (2020). Evaluation of the relative feed value of indigenous savanna forage shrub species in Ghana. African Journal of Plant Science, 14(2), 57-64. https://doi.org/10.5897/AJPS2019.1820

Jing, S., and Malladi, A. (2020). Higher growth of the apple (Malus $\times$ domestica Borkh.) fruit cortex is supported by resource intensive metabolism during early development. BMC Plant Biology, 20(1), 1-19. https:// doi.org/10.1186/s12870-020-2280-2

Lounglawan, P., Longlawan, W., Sulesombat. (2013). Effect of cutting interval and cutting height on yield and chemical composition of King Napier grass (Penisetum purpureum x Pennisetum americanum). APCBEE Procedia, 8, 27-31. https://doi.org/10.1016/j. apcbee.2014.01.075

Masters, D. G., Norman, H. C., and Thomas, D. T. (2020). Minerals in pastures-are we meeting the needs of livestock?. Crop and Pasture Science, 70(12), 1184-1195. https://doi.org/10.1071/CP18546

Paramananthan, S. (2000). Soils of Malaysia: Their Characteristics and Identification. Vol. 1. Academy of Sciences. Kuala Lumpur, Malaysia.

Rahman, M. M., Syafieqa, N. E., Diah, N. A. B. M., Gondo, T., Khalif, R. I. A. B. R., and Akashi. R. (2019). Growth characteristics, biomass yield and mineral concentrations in seven varieties of Napier grass (Cenchrus purpureus) at establishment in Kelantan, Malaysia. Tropical Grasslands-Forrajes Tropicales, 7(5), 538-543. https://doi. org/10.17138/tgft(7)538-543

Rambau, M. D., Fushai, F., and Baloyi, J. J. (2016). Productivity, chemical composition and ruminal degradability of irrigated Napier grass leaves harvested at three stages of maturity. South African Journal of Anima/ Science, 46(4), 398-408. https://doi.org/10.4314/sajas.v46i4.8

Turano, B., Tiwari, U. P., and Jha, R. (2016). Growth and nutritional evaluation of Napier grass hybrids as forage for ruminants. Tropical GrasslandsForrajes Tropicales, 4(3), 168-178. https://doi.org/10.17138/ TGFT(4)168-178

Van Soest, P. V., Robertson, J. B., and Lewis, B. A. (1990). Methods for dietary fiber, neutral detergent fiber, and nonstarch polysaccharides in relation to animal nutrition. Journal of Dairy Science, 74(10), 35833597. https://doi.org/10.3168/jds.S0022-0302(91)78551-2

Wadi, A., Ishii, Y., and Idota, S. (2014). Effects of cutting interval and cutting height on dry matter yield and over wintering ability at the established year in Pennisetum species. Plant Production Science, 7. 88-96. https://doi.org/10.1626/pps.7.88

Zailan, M. Z., Yaakub, H., and Jusoh, S. (2016). Yield and nutritive value of four Napier (Pennisetum purpureum) cultivars at different harvesting ages. Agriculture and Biology Journal of North America, 7, 213-219. 